\title{
A comparison of immunotoxic effects of nanomedicinal products with regulatory immunotoxicity testing requirements
}

This article was published in the following Dove Press journal:

International Journal of Nanomedicine

22 June 2016

Number of times this article has been viewed

\section{Christina Giannakou' ${ }^{1,2}$ \\ Margriet VDZ Park' \\ Wim $\mathrm{H}$ de Jong' \\ Henk van Loveren ${ }^{1,2}$ \\ Rob J Vandebriel' \\ Robert E Geertsma'}

'Centre for Health Protection, National Institute for Public Health and the Environment (RIVM), Bilthoven, ${ }^{2}$ Department of Toxicogenomics, Maastricht University, Maastricht, the Netherlands
Correspondence: Christina Giannakou Centre for Health Protection, National Institute for Public Health and Environment (RIVM), PO Box I, 3720 BA, Bilthoven, the Netherlands Tel +3I 302744172

Email christina.giannakou@rivm.nl
Abstract: Nanomaterials (NMs) are attractive for biomedical and pharmaceutical applications because of their unique physicochemical and biological properties. A major application area of NMs is drug delivery. Many nanomedicinal products (NMPs) currently on the market or in clinical trials are most often based on liposomal products or polymer conjugates. NMPs can be designed to target specific tissues, eg, tumors. In virtually all cases, NMPs will eventually reach the immune system. It has been shown that most NMs end up in organs of the mononuclear phagocytic system, notably liver and spleen. Adverse immune effects, including allergy, hypersensitivity, and immunosuppression, have been reported after NMP administration. Interactions of NMPs with the immune system may therefore constitute important side effects. Currently, no regulatory documents are specifically dedicated to evaluate the immunotoxicity of NMs or NMPs. Their immunotoxicity assessment is performed based on existing guidelines for conventional substances or medicinal products. Due to the unique properties of NMPs when compared with conventional medicinal products, it is uncertain whether the currently prescribed set of tests provides sufficient information for an adequate evaluation of potential immunotoxicity of NMPs. The aim of this study was therefore, to compare the current regulatory immunotoxicity testing requirements with the accumulating knowledge on immunotoxic effects of NMPs in order to identify potential gaps in the safety assessment. This comparison showed that immunotoxic effects, such as complement activation-related pseudoallergy, myelosuppression, inflammasome activation, and hypersensitivity, are not readily detected by using current testing guidelines. Immunotoxicity of NMPs would be more accurately evaluated by an expanded testing strategy that is equipped to stratify applicable testing for the various types of NMPs.

Keywords: nanomedicine, regulatory requirements, safety, testing methods, immunotoxicity

\section{Introduction}

Nanomaterials (NMs) are increasingly used in a wide variety of applications, including pigments in paint, antibacterial coatings, and ultraviolet filters in sunscreens, due to their unique physicochemical properties. One of the most active research fields of NM applications is nanomedicine, ${ }^{1}$ defined by the European Science Foundation ${ }^{2}$ as:

The science and technology of diagnosing, treating and preventing disease and traumatic injury, of relieving pain, and of preserving and improving human health, using molecular tools and molecular knowledge of the human body. ${ }^{2}$

This article focuses on nanomedicine applications, which are regulated as medicinal products. Expectations for the benefits of these so-called nanomedicinal products (NMPs) are high. ${ }^{3,4}$ NMPs can have a great impact in health care, including a reduction 
in costs as well as a contribution to the concept of personalized medicine. ${ }^{5}$ Research is ongoing for their use as an alternative in therapeutics for many different diseases. One of the key aims of developing NMPs is the minimization of unwanted side effects. ${ }^{6-8}$ Furthermore, due to their small size, the transport through the different biological barriers is expected to be enhanced, resulting in an improved transport and delivery of the therapeutic compounds to the target tissue. ${ }^{4,8,9}$ In addition, characteristics of NMPs, such as surface area, composition, and surface coating, can be designed to fit the particular purpose of a drug. ${ }^{6,8}$

NMPs that are already used in the clinic include a range of therapeutic products, as well as contrast agents for magnetic resonance imaging (MRI). ${ }^{7,10}$ Various types of nanoformulations used in drug delivery are presented in Figure $1 .{ }^{11}$

Although one of the major benefits claimed for many NMPs is a reduction in unwanted side effects, the use of NMPs does not guarantee the absence of side effects. Systemically available NMPs have the tendency to end up in lymphoid organs, such as the spleen, ${ }^{12,13}$ and interactions of NMPs and NM with the immune system play a leading role in the intensity and extent of side effects occurring simultaneously with the therapeutic activity. ${ }^{14}$

The immune system is the body's defense against the invasion of foreign material and is also responsible for maintaining the body's homeostasis. Many adverse immune effects were reported after conventional medicinal product administration, including allergy, anaphylaxis, hypersensitivity, and immunosuppression. ${ }^{15}$ In fact, it was reported that $10 \%-20 \%$ of the medicinal products removed from clinical practice between 1969 and 2005 were withdrawn due to immunotoxic effects. ${ }^{16,17}$ A careful investigation of the immunosafety profile of any medicinal product, including NMPs, is therefore of high importance. ${ }^{16,18}$

As with any medicinal product, the quality, efficacy, and safety of NMPs need to be evaluated and approved by regulatory bodies (eg, European Medicines Agency [EMA], US Federal Drug Administration [USFDA], Health Canada [HC], and the Japanese Pharmaceuticals and Medical Devices Agency) before the products can enter the market. Generally, pharmaceutical companies need to demonstrate the quality, efficacy, and safety of their product based on the results of analytical testing, in vitro and in vivo nonclinical studies, and clinical trials, covering all aspects relevant to their product. Studies addressing the safety aspects are generally performed using harmonized guidelines, such as those defined by the International Council for Harmonization of Technical Requirements for Pharmaceuticals for Human Use (ICH).
Currently, there are no regulatory guidance documents specifically dedicated to evaluate the immunotoxicity of NMPs. Assessment of immunotoxicity of NMPs is performed based on existing guidelines for conventional medicinal products, including the ICH S8 guideline on immunotoxicity studies for human pharmaceuticals. Due to the differences between conventional medicinal products and NMPs, it can be questioned whether the currently prescribed set of testing methods provides sufficient information for an adequate evaluation of potential immunotoxic effects of NMPs.

The aim of this review was to compare the present guidelines for the assessment of potential adverse effects of medicinal products on the immune system with the increasing knowledge on effects of NMPs, both marketed and under development, in order to identify potential gaps in the safety evaluation.

\section{What are NMPs? Definitions}

Various definitions of NMs and NMPs are used in regulations and scientific literature, but most refer to materials with a size range between $1 \mathrm{~nm}$ and $100 \mathrm{~nm}$ in one, two, or three dimensions., ${ }^{3,19-22}$ Although by this definition, a nanosheet with a $1 \mathrm{~nm}$ thickness is also considered as a $\mathrm{NM}$, the term NM mostly refers to particulate structures consisting of solid materials for which the terms NMs and nanoparticles (NPs) are used interchangeably. The EMA defines nanotechnology as "the use of tiny structures - less than 1,000 $\mathrm{nm}$ across - that are designed to have specific properties". ${ }^{23}$ Nanomedicines are purposely designed, often using multiple components. The rationale for their design includes improved drug delivery, eg, drug targeting (organ specific, cell specific, or subcellular targeting), controlled and/or site-specific release, and improved drug transport across biological barriers. ${ }^{24} \mathrm{~A}$ similar approach to define nanomedicine is used by the USFDA and HC. The working definitions of both $\mathrm{HC}$ and the USFDA determine the nanoscale as ranging up to $100 \mathrm{~nm}$ size. Nevertheless, further information may also be asked from the manufacturer by $\mathrm{HC}$ for products with sizes up to 1,000 $\mathrm{nm}$ within particular regulatory programs. Also the USFDA reserves the right, for the time being, to perform specific evaluation of engineered materials or end products up to $1,000 \mathrm{~nm}^{25,26}$

Depending on the definition used, the number of nanomedicines marketed and under development varies. ${ }^{10,27}$ Using EMA's definition, Noorlander et $\mathrm{al}^{27}$ reported recently that 175 NMPs are on the market or in clinical trials. Of these products, 43 NMPs were approved by EMA, 71 NMPs were 


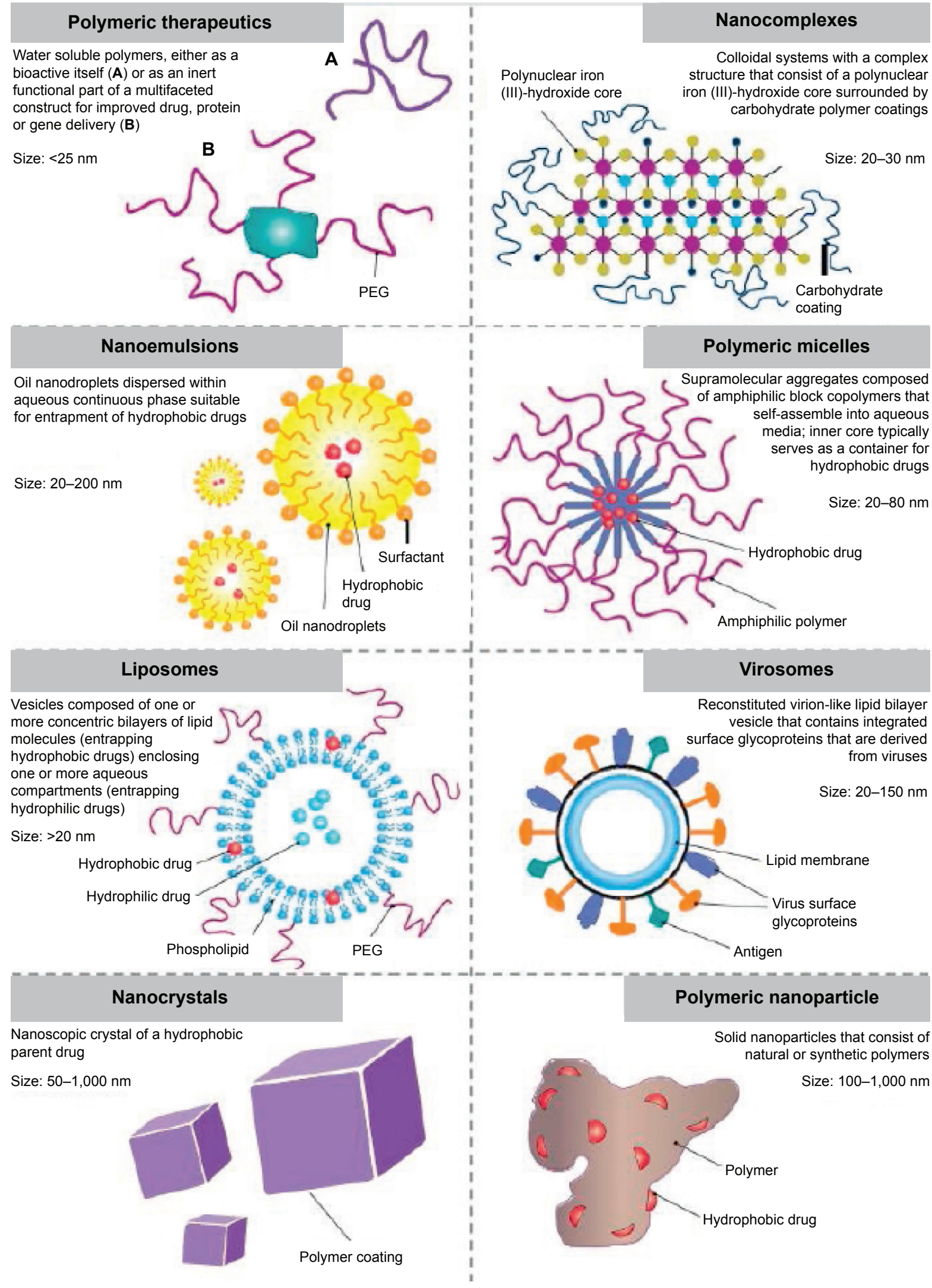

Figure I Nanoformulations in medicinal products.

Notes: Copyright @20 I4. Dove Medical Press. Reproduced from Hafner A, Lovric J, Lakos GP, Pepic I. Nanotherapeutics in the EU: an overview on current state and future directions. Int J Nanomedicine. 20 I4;9: 1005-1023."1

Abbreviation: PEG, polyethylene glycol. 
approved by the USFDA, and 101 NMPs were in various stages of clinical trials. ${ }^{27}$

\section{Categories of NMPs according to their type of application}

NMPs can be categorized according to their type of application: diagnostic and therapeutic. A very low number of NMPs is already integrated in clinical practice for diagnostic purposes. According to Kiessling et al, ${ }^{13}$ this absence of clinical use of different diagnostic NMPs has been linked to problems of developing NMPs with adequate pharmacokinetic characteristics and reproducible consistency, and considerations on toxicity, biodegradation, and elimination could be other factors. ${ }^{13}$ Iron oxide NMPs have been used but are currently no longer on the market. As a different example, $\mathrm{Gd}_{2} \mathrm{O}_{3} @ \mathrm{SiO}_{2}$ core-shell $\mathrm{NM}$ is an example of an NM under development as a contrast agent for MRI in cancer diagnosis. It shows adequate magnetic resonance contrast accompanied with limited cytotoxicity and immunotoxicity. ${ }^{28}$ Feraheme (ferumoxytol) is an iron-based NMP administered for the treatment of iron deficiency anemia in adult patients with chronic kidney disease. ${ }^{29}$ During the last decade, ferumoxytol has also been investigated for application as a contrast agent in MRI. ${ }^{30-33}$ It is an iron-based agent with no potential for causing nephrogenic systemic fibrosis as gadolinium-based contrast agents and, therefore, considered to be an attractive candidate product. ${ }^{34}$

So far, therapeutic drug delivery systems are dominating nanomedicine ${ }^{1,35}$ and represent $>75 \%$ of total sales. ${ }^{1}$ The majority of the NMPs already marketed consist of liposomal products and polymer conjugates. ${ }^{27,36}$ An example of a liposomal nanoformulation is DOXIL ${ }^{\circledR}$, which contains the chemotherapeutic drug doxorubicin. DOXIL ${ }^{\circledR}$ was the first NMP that gained regulatory approval. It is used to treat patients suffering from AIDS-related Kaposi's sarcoma, ovarian cancer, and multiple myeloma. The benefit of this NMP compared to the conventional drug, free doxorubicin, is that the cardiotoxicity of the drug is reduced due to the altered toxicokinetics resulting in reduced levels of doxorubicin in the heart, accompanied by higher accumulation in the malignant tissue. Furthermore, a reduction in the effective therapeutic dose is possible. ${ }^{4}$ An example of a polymer conjugate is Neulasta $^{\circledR}$, a covalent conjugate of recombinant methionyl human granulocyte-colony stimulating factor (filgrastim) and monomethoxypolyethylene glycol. It is prescribed for reduction of the risk of infection due to a low white blood cell count in patients suffering from certain types of cancer (nonmyeloid) and receiving chemotherapy that can cause fever and low blood cell count. ${ }^{27,37}$ Migration of particulate NMPs in the tumor is promoted by the relatively poor quality of the blood vessels, which have gaps in their endothelial lining. ${ }^{38}$ This results in the so-called enhanced permeability and retention effect that favors NMPs' accumulation at solid tumor sites. ${ }^{36}$

In some cases, NMPs can function both as diagnostic and therapeutic agents, the so-called theranostics. ${ }^{13}$ An example of theranostics is the use of magnetoplasmonic NP assemblies for cancer theranostics. Chen et $\mathrm{al}^{39}$ developed a magnetoplasmonic nanostructure for the treatment and diagnosis of cancer. These nanostructures were able to demonstrate high contrast magnetic resonance images and high apoptosis rates in leukemic cells in vitro. ${ }^{39}$ Another example is a fullerene-based theranostic, in particular gadolinium endohedral fullerene, designed as an MRI contrast agent able to pass the blood-brain barrier that can also deliver a therapeutic compound to highly malignant glioblastoma. This theranostic was tested in vivo displaying selective targeting and reduction in human brain tumors, which were previously transplanted in mice. ${ }^{40}$

\section{Categories of NMPs according to innovation status}

NMPs can also be categorized as follows: first-generation NMPs, nanosimilars, and second-generation NMPs. Firstgeneration NMPs are already established and used in clinical practice today. For some of these NMPs, mainly liposomes and iron oxides, the patents have expired or will do so in the near future, and follow-on nanomedicines are expected to enter the market soon. ${ }^{1,10,11,24}$ These new products have been termed as "nanosimilars". ${ }^{24}$ Similarity is determined based on aspects of quality, efficacy, and safety and should be demonstrated before the product is granted market authorization. The last category includes new and more technologically complex "second-generation NMPs", which are still under development. ${ }^{1,10,11,24}$ An important type of second-generation NMPs is based on block copolymer micelles. ${ }^{24}$ An example is the development of nanomicelles based on cationic mPEG2000-PLA3000-b-R15 copolymer, tested in vitro on MCF-7 cells and erythrocytes directly isolated from rats and in vivo in a mouse model. ${ }^{41}$ Zhao et $\mathrm{al}^{41}$ reported that these nanomicelles can be regarded as a safe and efficient nanocarrier for in vivo delivery of therapeutic siRNA. Another example is the use of polymeric micelles that are constituted by amphiphilic block copolymers. This nanoformulation was regarded suitable for the encapsulation of poorly watersoluble, hydrophobic medicinal products and can be applied in cancer treatment. ${ }^{42}$ Due to limited experience with the 
evaluation of these products, nanosimilars and secondgeneration NMPs constitute a challenge for manufacturers and regulators who have to ensure that safe products enter the market. ${ }^{24}$

\section{The immune system and immunotoxicity of medicinal products}

The immune system is responsible for maintaining healthy homeostasis through host protection from pathogens and monitoring the body to effectively identify and remove damaged and dead cells. Functional and structural changes of the immune system can result in a variety of pathophysiological conditions and diseases. ${ }^{43}$ Taking into account that the role of the immune system is to recognize and eliminate possible threats that come into contact with the body, preservation of its good condition is important to maintain the integrity of the organism. ${ }^{18}$

There may be different consequences of perturbation of the immune system by xenobiotics. One is direct toxicity of the xenobiotic for cells and organs of the immune system leading to malfunction of the immune system, potentially resulting in decreased resistance to infection or reduced defenses against neoplasms. Specific responses of the immune system can be of a cellular or of a humoral nature. For instance, T-cell-mediated hypersensitivity after exposure to abacavir ${ }^{44}$ and anaphylaxis induction by penicillin. ${ }^{45}$ Nonspecific interactions with components of the immune system may, eg, involve mast cells, leading to a pseudoallergic reaction. Xenobiotics may also be recognized by the immune system as a "threat" resulting in allergy, or they may alter self-components so that the immune system no longer recognizes certain components as self, resulting in autoimmunity. Direct toxicity of xenobiotics to components of the immune system may also aggravate adverse effects on the immune system caused by other factors, ie, allergic or autoimmune phenomena that are not caused by the xenobiotic itself but are evident or latently present because of other reasons. An example of this is an inadvertent adjuvant activity, where the xenobiotic aggravates an allergic response to another stimulant.

With regard to conventional medicines, autoimmunity occurs quite rarely. ${ }^{15}$ Serious responses to medicinal products include higher susceptibility to infections ${ }^{46}$ and virus-induced malignancies ${ }^{46,47}$ as a result of immunosuppression. Several epidemiological studies have demonstrated an inhibition of resistance to infectious agents. However, the major druginduced immunotoxic effects are specific or nonspecific hypersensitivity-like reactions. For example, nonspecific hypersensitivity or so-called "pseudoallergy" can be caused by nonsteroidal anti-inflammatory medicinal products, analgesics, and morphine. ${ }^{48,49}$

Most undesirable adverse effects of medicinal products are predictable as they are initiated by the known pharmacological or toxicological activity of the active pharmaceutical ingredient. Nevertheless, in $16 \%$ of all cases, idiosyncratic side effects are observed that cannot be predicted. The majority of these unpredictable side effects are regarded as immune-mediated hypersensitivity reactions to medicinal products.

\section{The immune system and NMs}

A large body of knowledge is evolving on the interactions of NMs with the immune system. Most of this knowledge is also relevant to NMPs. Studies on toxicokinetics of intravenously administered NMs, such as gold NPs (AuNPs), silver NPs (AgNPs), and titanium dioxide $\left(\mathrm{TiO}_{2}\right) \mathrm{NPs}$, have shown that most of the NMs end up in immune-related organs containing cells of the mononuclear phagocytic system (MPS), notably in the liver and the spleen ${ }^{50-52}$ Only a small fraction of the administered dose showed a more widespread tissue distribution beyond the liver and spleen with the smallest NPs reaching most organs. ${ }^{50}$ Immune cells, such as monocytes, platelets, leukocytes, dendritic cells, and macrophages, recognize and take up NMs, while they are still in the circulation or when present in tissues, such as liver (Kupffer cells) and spleen (macrophages). There are several pathways that immune cells use to take up NM, and they can be facilitated by the adsorption of opsonins on the surface of the particle. Opsonization can happen at the exact time point when the NM enters the bloodstream. After the NMs are taken up by the immune cells, their fate depends on their biodegradability. Biodegradable NMs are digested and, thus, facilitate elimination, but nondegradable NMs can be stored in the cells for long periods of time. ${ }^{53}$ Variation of the characteristics of NMs, such as size, shape, surface charge, density, crystallinity, zeta potential, and extent and nature of the surface modification, could lead to changes in the distribution pattern and to variation in their persistence in the body. Different studies demonstrate that toxic effects to the immune system may depend on the size of the NMs. In vivo inhalation exposure of rats to different sizes of AgNPs demonstrated a size-dependent toxicity in the lungs compared to the controls. ${ }^{54}$ Size-dependent effects of AgNPs were not only demonstrated after in vivo mammalian exposure but also following the exposure of microbial species, protozoans, 
algae, crustaceans, and mammalian cells in vitro. ${ }^{55}$ Studies also showed dependency of toxic effects on the size of the NMs after the exposure of AuNPs to murine fibroblasts. ${ }^{56}$ The finding that immunotoxic effects may change with small changes in size (or likely also with small changes in other physicochemical properties) demonstrates that results of one NM cannot readily be extrapolated to another NM, even if they have the exact same chemical composition. This implies that batches of NMs need to be highly controlled, not only in terms of their chemical composition and purity, but also in terms of their physicochemical properties, such as size. The properties of the surface of NMs, thus, have a large impact on their biological behavior and, in turn, on their potential effects on the immune system.

Several studies have shown that a naked NP does not exist in the body but is quickly covered with all kinds of biomolecules forming the so-called "corona". ${ }^{57-59}$ Although often referred to as protein corona, also other molecules, such as lipids, can adhere to the NMs. ${ }^{57,60}$ The effect of the corona on the distribution and biocompatibility of NMs is not well understood yet.

Recognition of NMs by the immune system as foreign material can result in responses leading to their elimination. Additionally, immune-mediated elimination of NMs can induce intense manifestations that may lead to pathologies, such as complement activation, and may induce acute inflammation. ${ }^{18}$ Toxicity may include immunotoxic effects in the broadest sense, ie, effects on innate immune responses and effects on specific immune responses.

Induction of inflammation can be triggered through NF- $\kappa B$ pathway activation, as indicated by the enhanced production of cytokines and chemokines. ${ }^{7,8}$ Another mechanism that leads to adverse effects on the innate immune system is the excessive production of reactive oxygen species (ROS), ${ }^{7,8}$ which is often observed after exposure to metal and metal oxide particles. ${ }^{61}$ In vitro exposure to these NPs and the resulting excessive production of ROS may induce oxidative stress, eventually leading to cell death if the antioxidant resources in the cells are insufficient. ${ }^{62} \mathrm{ROS}$ can also lead to inflammation and changes in proteins and DNA, which in turn leads to inflammatory damage. .2,63 $^{62}$

An example of NMs presenting immunomodulatory effects is that of AuNPs, which find different applications including medical uses, such as contrast agents for imaging, drug delivery, and hyperthermia treatment. ${ }^{64}$ AuNPs can have various surface charges and coatings, which are reported in literature to induce immunomodulatory effects. ${ }^{8}$ For instance, Deng et $\mathrm{a}^{65}$ reported NF- $\mathrm{kB}$ pathway activation and secretion of inflammatory cytokines (TNF $\alpha$ and IL-8) after exposure of THP1 cells to negatively charged poly(acrylic acid)-coated AuNPs. In addition, Sharma et $\mathrm{al}^{66}$ reported changes in cellular function and induction of NF- $\mathrm{kB}$-regulated luciferase reporter of murine B-lymphocyte cells after exposure to citrate-stabilized $10 \mathrm{~nm}$ AuNPs. Other examples of immunomodulatory effects by NMs are the induction of improper antigen-presenting cell maturation after exposure to multiwalled carbon nanotubes (MWCNT) and single-walled carbon nanotubes (CNT) ${ }^{67,68}$ and Th1/Th2 balance shift after exposure to iron oxides, $\mathrm{TiO}_{2}$ and $\mathrm{CeO}_{2}{ }^{69,70}$

Exposure to CNT resulted in adverse effects in various cell types in vitro, including those with immune-related functions, such as macrophages $(\mathrm{m} \phi)(\mathrm{rat}$ alveolar $\mathrm{m} \phi$ [NR8383] and THP1-derived $\mathrm{m} \phi$ ), human microvascular endothelial cells, human epidermal keratinocytes, human bronchial epithelial (BEAS-2B), human mesothelial (MeT-5A) cells, and lymphoblastoid (MCL-5) cells. ${ }^{71}$ In vivo studies have shown depletion of antioxidants, increased intracellular production of ROS, and proinflammatory signaling, resulting in fibrosis and neoplastic changes in the lungs of mice and rats and elevated risk of cardiopulmonary diseases by generation of a proinflammatory and prooxidant milieu in the lungs. ${ }^{71}$ For nanosilver, immunosuppression was observed after 28-day repeated dose intravenous administration to Wistar rats, ${ }^{72,73}$ although no immunotoxicity was observed in another study using oral administration. ${ }^{74}$

Some NMs can interact with the immune system in a direct way through toll-like receptors (TLRs). ${ }^{75}$ Proteins of the complement cascade are not only able to stimulate the immune system independently with effects as those mentioned earlier, but they can also act in a synergistic way with TLRs to increase inflammation. TLRs are also able to lead to immune reactions independently from the complement cascade. TLR stimulation by agonists might result in extreme production of proinflammatory cytokines. ${ }^{4}$ For instance, it has been reported that silica and titanium dioxide NPs are able to suppress the expression of TLR9 receptor and faltering of the $\mathrm{CpG}$ oligonucleotides but on the other hand increase TLR4-mediated LPS-induced production of proinflammatory cytokines. ${ }^{76}$

In addition, for NMs quite frequently hypersensitivity and immunosuppressive and anti-inflammatory effects are reported and less often autoimmunity. ${ }^{77}$ Recently, the induction of protein citrullination by NMs was reported, which may potentially lead to triggering of autoimmune diseases. ${ }^{78,79}$

Autophagy is an evolutionarily conserved intracellular process ${ }^{79}$ that has a leading role in inflammatory and 
immune responses. ${ }^{80}$ Silica NPs can disturb the homeostasis of endothelial cells and affect angiogenesis. Duan et a $1^{81}$ reported that Silica NPs are able to generate VEGFR2mediated autophagy in endothelial cells and pericytes. More NMs' types have recently been reported to be able to induce autophagy in different cell types, through Akt-TSC2-mTOR signaling or potentially as a result of excessive oxidative stress induction. ${ }^{82-84}$ A summary of the effects of NMs on the immune system is presented in Table 1 .

\section{The immune system and NMPs as a special group of NMs}

Interactions with the immune system

Similar to what has been found for other NMs, physicochemical characteristics, including size, surface charge, coatings, and other surface characteristics influence the behavior of NMPs and thus their interaction with the immune system..$^{10,24}$ In addition, the toxic profile of NMPs, including their immunotoxic profile, is determined by combined effects of

Table I Examples of immunotoxic effects reported after in vitro or in vivo testing of nanomaterials

\begin{tabular}{|c|c|c|c|c|}
\hline Adverse side effects & Nanomaterial & $\begin{array}{l}\text { Average } \\
\text { size }(\mathrm{nm})\end{array}$ & Testing method & References \\
\hline Inflammation due to ROS production & $\begin{array}{l}\text { Nonporous silica } \\
\text { nanoparticles }\end{array}$ & 15 & $\begin{array}{l}\text { In vivo animal model } \\
\text { Male SD rats } \\
\text { Intravenous administration - single } \\
\text { dose }\end{array}$ & 137 \\
\hline ROS production & Carbon black & 14 & $\begin{array}{l}\text { In vitro } \\
\text { A549, CaCo, CaLu3, HaCaT, MDCK, } \\
\text { MDCK2, RAW264.7, NIH3T3, } \\
\text { NRK52E, and RLE6TN }\end{array}$ & 62 \\
\hline ROS production and cell apoptosis & Titanium dioxide $\left(\mathrm{TiO}_{2}\right) \mathrm{NPs}$ & 21 & $\begin{array}{l}\text { In vitro } \\
\text { Beas-2B }\end{array}$ & 138 \\
\hline $\begin{array}{l}\text { NF-KB pathway activation } \\
\text { Inflammatory cytokine secretion } \\
\text { (TNF-alpha and IL-8) }\end{array}$ & $\begin{array}{l}\text { Negatively charged PAA- } \\
\text { AuNPs }\end{array}$ & - & $\begin{array}{l}\text { In vitro } \\
\text { THP-I cells }\end{array}$ & 65 \\
\hline $\begin{array}{l}\text { Modification of cellular function } \\
\text { NF- } \kappa B-\text { regulated luciferase reporter } \\
\text { induction }\end{array}$ & Citrate-stabilized AuNPs & 10 & $\begin{array}{l}\text { In vitro } \\
\text { Murine B-lymphocyte cell line } \\
(\mathrm{CH} \text { I2.LX) }\end{array}$ & 66 \\
\hline $\begin{array}{l}\text { Improper antigen presenting cell } \\
\text { maturation } \\
\text { Partly exacerbate in vivo murine allergic } \\
\text { airway inflammation by promotion of } \\
\text { induction of T-helper immune responses }\end{array}$ & MWCNT & - & $\begin{array}{l}\text { In vitro } \\
\text { Bone marrow-derived DC } \\
\text { In vivo } \\
\text { ICR mice }\end{array}$ & 67 \\
\hline $\begin{array}{l}\text { Improper antigen-presenting cell } \\
\text { maturation } \\
\text { Exacerbate in vivo murine allergic airway } \\
\text { inflammation by promotion of induction } \\
\text { of T-helper immune responses }\end{array}$ & SWCNT & - & $\begin{array}{l}\text { In vitro } \\
\text { Bone marrow-derived DC } \\
\text { In vivo } \\
\text { ICR mice }\end{array}$ & 68 \\
\hline Delayed-type hypersensitivity (DTH) & $\begin{array}{l}\text { Resovist }^{\circledR} \text { (Bayer AG, } \\
\text { Leverkusen, Germany) }\end{array}$ & 58.7 & $\begin{array}{l}\text { In vivo } \\
\text { Male BALB/c mice } \\
\text { Intravenous administration I hour } \\
\text { before ovalbumin sensitization }\end{array}$ & 70 \\
\hline $\begin{array}{l}\text { Inflammatory responses via ROS, } \\
\text { inflammasome, IL-I beta pathway }\end{array}$ & Titanium dioxide $\left(\mathrm{TiO}_{2}\right) \mathrm{NPs}$ & $7-10$ & $\begin{array}{l}\text { In vitro } \\
\text { PBMC-derived DC }\end{array}$ & 69 \\
\hline ThI/Th2 balance shift & Cerium oxide $\left(\mathrm{CeO}_{2}\right)$ & $3-5$ & $\begin{array}{l}\text { In vitro } \\
\text { PBMC-derived DC }\end{array}$ & 69 \\
\hline Inflammation and oxidative stress & CNT & - & $\begin{array}{l}\text { In vitro } \\
\mathrm{m} \phi \text { (rat alveolar m } \phi \text { [NR8383], human } \\
\text { THPI-derived } \mathrm{m} \phi \text { ) } \\
\text { Human microvascular endothelial cells } \\
\text { Human epidermal keratinocytes } \\
\text { Human bronchial epithelial (BEAS-2B) } \\
\text { cells } \\
\text { Human mesothelial (MeT-5A) cells } \\
\text { Lymphoblastoid (MCL-5) cells }\end{array}$ & 71 \\
\hline
\end{tabular}


Table I (Continued)

\begin{tabular}{|c|c|c|c|c|}
\hline Adverse side effects & Nanomaterial & $\begin{array}{l}\text { Average } \\
\text { size }(\mathrm{nm})\end{array}$ & Testing method & References \\
\hline $\begin{array}{l}\text { Generation of a pro-inflammatory and } \\
\text { pro-oxidant environment in the lungs }\end{array}$ & CNT & - & Mice and rats & 71 \\
\hline Immunosuppression & AgNPs & $\begin{array}{l}20 \\
100\end{array}$ & $\begin{array}{l}\text { 28-Day repeated dose } \\
\text { Intravenous administration to Wistar } \\
\text { rats }\end{array}$ & 72,73 \\
\hline TLR exploitation & PVM/MA NPs & $230 \pm 5$ & $\begin{array}{l}\text { In vitro } \\
\text { Mouse DC from mouse femur bone } \\
\text { marrow precursors } \\
\text { In vivo } \\
\text { C57/BL6 } \\
\text { ip administration }\end{array}$ & 75 \\
\hline $\begin{array}{l}\text { Suppress the expression of } \\
\text { TLR9 and altering of the CPG } \\
\text { oligonucleotides } \\
\text { Increase of TLR4-mediated LPS-induced } \\
\text { production of pro-inflammatory } \\
\text { cytokines }\end{array}$ & $\begin{array}{l}\text { Titanium dioxide }\left(\mathrm{TiO}_{2}\right) \mathrm{NPs} \\
\text { Silicon dioxide }\left(\mathrm{SiO}_{2}\right) \mathrm{NPs} \\
\text { Zirconium dioxide } \\
\left(\mathrm{ZrO}_{2}\right) \mathrm{NPs} \\
\mathrm{Co} \mathrm{NPs}\end{array}$ & $\begin{array}{l}\mathrm{TiO}_{2} 70 \\
\mathrm{SiO}_{2} \mathrm{I5} \\
\mathrm{ZrO}_{2} 5-30 \\
\mathrm{Co} 50-200\end{array}$ & $\begin{array}{l}\text { In vitro } \\
\text { Human m } \phi \text { PMA-differentiated } \\
\text { myelomonocytic U-937 cells }\end{array}$ & 76 \\
\hline $\begin{array}{l}\text { Post-translational citrullination of } \\
\text { proteins }\end{array}$ & $\begin{array}{l}\text { Silicon dioxide }\left(\mathrm{SiO}_{2}\right) \mathrm{NPs} \\
\text { Positively charged alumina- } \\
\text { coated chloride ion- } \\
\text { stabilized } \mathrm{SiO}_{2} \mathrm{NPs}\left(\mathrm{Al}-\mathrm{SiO}_{2}\right. \\
\mathrm{NPs}) \\
\mathrm{Sc}^{-\mathrm{SiO}_{2}} \mathrm{NPs} \\
\mathrm{SWCNT}\end{array}$ & $\begin{array}{l}\mathrm{SiO}_{2} \mathrm{NPs} \\
30,80 \text {, and } \\
400 \\
\mathrm{Al}^{-S i O}{ }_{2} \\
\mathrm{NPs} 40 \\
\mathrm{Sc}-\mathrm{SiO}_{2} \\
\mathrm{NPs} 20 \\
\mathrm{SWCNT} \text { : } \\
\text { mean } \\
\text { diameter } \\
\mathrm{I}-4 \mathrm{~nm} \\
\text { and length } \\
\mathrm{I}-3 \mu \mathrm{m}\end{array}$ & $\begin{array}{l}\text { In vitro } \\
\text { A549 and THPI cells } \\
\text { In vivo } \\
\text { C57BL/6 mice - inhalatory exposure }\end{array}$ & 78,79 \\
\hline $\begin{array}{l}\text { Generation of VEGFR2-mediated } \\
\text { autophagy }\end{array}$ & Silica NPs (SiNPs) & 62 & $\begin{array}{l}\text { In vivo } \\
\text { ICR mice }\end{array}$ & 81 \\
\hline $\begin{array}{l}\text { Autophagic cell death through the } \\
\text { Akt-TSC2-mTOR pathway in vitro } \\
\text { Acute lung injury in vivo }\end{array}$ & $\begin{array}{l}\text { PABS-, PEG-, or carboxylic } \\
\text { acid (COOH)-functionalized } \\
\text { SWCNT }\end{array}$ & - & $\begin{array}{l}\text { In vitro } \\
\text { Human lung adenocarcinoma A549 } \\
\text { cells } \\
\text { In vivo } \\
\text { BALB/c mice }\end{array}$ & 83 \\
\hline $\begin{array}{l}\text { Potential autophagy due to excessive } \\
\text { oxidative stress induction }\end{array}$ & AuNPs & 20 & $\begin{array}{l}\text { In vitro } \\
\text { MRC-5 human fetal lung fibroblast } \\
\text { cells }\end{array}$ & 82 \\
\hline
\end{tabular}

Abbreviations: AgNPs, silver nanoparticles; AuNPs, gold nanoparticles; CNT, carbon nanotubes; DC, dendritic cells; DTH, delayed-type hypersensitivity; ip, intraperitoneal; m申, macrophages; MWCNT, multiwalled carbon nanotubes; NPs, nanoparticles; PAA, poly(acrylic acid); PABS, polyaminobenzene sulfonic acid; PBMC, peripheral blood mononuclear cell; PEG, polyethylene glycol; PVM/MA, poly(methyl vinyl ether-co-maleic anhydride); ROS, reactive oxygen species; Sc-SiO, sodium counterion-stabilized $\mathrm{SiO}_{2}$; SiNPs, silica nanoparticles; SWCNT, single-walled carbon nanotubes; TLRs, toll-like receptors; ICR, Institute of Cancer Research; SD, Sprague Dawley; CpG, 5'-Cphoshate-G-3'; LPS, lipopolysaccharide; PMA, phorbol myristate acetate.

the nanocarrier, the active pharmaceutical ingredient, the potential coating, and the formulation of the final product. An example of the different parameters influencing the immunotoxic profile of NMPs is reported by Bastus et al. ${ }^{85}$ They showed that the addition of a peptide on the surface of gold NMs and the pattern that these peptides were conjugated on the surface of the NMs resulted in immune responses through proinflammatory cytokine secretion (Il-6, IL-1b, and TNF $\alpha$ ), while gold NMs alone did not. ${ }^{11}$ Uptake of NMPs by immune cells can lead to not reaching their target site and finally result in a lower number of NMPs, and thus a lower concentration of the active compound at the target tissue. Coating with polyethylene glycol (PEG) has been shown to enable escape from the MPS for a prolonged period of time, thereby increasing the half-life in blood. ${ }^{86,87}$ Dobrovolskaia et $\mathrm{al}^{60}$ reported recently that the molecular weight of PEG coating affected the total amount of protein binding. However, the types of proteins forming the protein corona were not influenced by 
the presence of PEGylation. ${ }^{60}$ While increasing half-life in blood may be an advantage for the therapeutic or diagnostic efficacy of NMPs, it is important to realize that a modulation of the kinetics and distribution of NMPs by applying various types and amounts of PEG coating may also modify its toxicity profile. ${ }^{18,35,63}$ Therefore, a balance of hydrophilic and hydrophobic coating is needed for an optimal circulation of NMPs in the system.

Just as there are nanoformulations designed to evade recognition by the immune system, eg, by PEG coating, there are also NMPs designed to specifically target the immune system. ${ }^{77}$ This may be useful, eg, as macrophages may be more abundantly present in diseased sites, such as tumors. ${ }^{36}$ In addition, NMPs may be able to modulate the immune system in an advantageous way. For example, PEG-coated graphene oxide (PEG-GO) is of interest for its potential application in imaging, drug delivery, and cancer therapy. Studies in mice show that the administration of PEG-GO resulted in uptake by the MPS, resulting in a potentially high exposure of immune cells to PEG-GO. ${ }^{88-90}$ A single administration of PEG-GO affected B-cell and T-cell immune responses against the model antigen ovalbumin (OVA). ${ }^{91}$ Immunoglobulin E-specific antibodies were decreased, whereas OVA-specific $\mathrm{T}$-cell responses were 0 enhanced as indicated by the increase in cytokine (interferon- $\gamma$ and IL-4) production of spleen cells after stimulation with OVA antigen. The authors suggested that PEG-GO might be useful as an immune modulator in view of its properties to suppress the immunoglobulin $\mathrm{E}$ responses and enhance both Th1 and Th2 cytokine production in spleen cells. Due to the particle scavenging role of immune cells, such as phagocytic and antigen-presenting cells, targeting the MPS and components of the immune system is much less problematic compared to other targets. ${ }^{18}$ Poly-D-L-lactide-co-glycolide (PLGA) NMs are considered safe to use with extremely low toxic effects. ${ }^{92}$ PLGA is a biodegradable polymer authorized for drug delivery systems in humans by USFDA and EMA. ${ }^{93}$ PLGA is metabolized in the body into lactic acid and glycolic acid monomers. These two monomers can be adequately managed by the body, and biodegradable PLGA can be used in therapeutic drugs for different diseases, including cancer, inflammatory diseases, and infections. There are many different PLGA and PLGA-based nanosized formulations in the preclinical phase. ${ }^{94}$

\section{Hypersensitivity}

Whether intentionally targeting the immune system or not, most NMPs will eventually interact with this system as they are generally cleared from the circulation by the cells of the
MPS, signifying the importance of evaluating their potential immunotoxic effects. Especially for intravenously administered NMPs, interaction with blood needs to be investigated carefully. An initially unexpected but now well-known and investigated adverse effect of liposomal drug formulations is the activation of the complement system resulting in an acute pseudoallergic hypersensitivity reaction called complement activation-related pseudoallergy (CARPA). ${ }^{49,95}$ Possible explanations why NMPs generate immunotoxic reactions, such as CARPA, are thought to involve misinterpretation by the immune system of NMPs as a pathogen (eg, DOXIL ${ }^{\circledR}$ as observed in cryo-transmission electron microscopy resembles the HIV-1 virus) and the lack of membrane proteins that protect host cells from complement attack. ${ }^{96}$ CARPA induction was reported for radio contrast media, ${ }^{97}$ micelles loaded with amphiphilic lipids (such as Cremophor ${ }^{\circledR}$ EL), ${ }^{98}$ synthetic block copolymers (eg, poloxamer 188), ${ }^{99}$ and liposomal nanoformulations (including DOXIL ${ }^{\circledR 100}$ and AmBisome $\left.^{\circledR}\right),{ }^{101}$ after the first intravenous administration. ${ }^{49,95}$ CARPA can pose a threat to life for a small group of patients, ${ }^{95}$ with the incidence of severe and fatal reactions being $\sim 7 \%$ and $\sim 0.3 \%$, respectively. ${ }^{102}$ It is recognized today as an important immunotoxicity effect in the pharmaceutical nanotechnology field. CARPA symptoms are very similar to those of a common allergic response, but a few indicators are unique to CARPA. The reaction is observed after the first administration, without prior exposure to the allergen and becomes milder upon repeated administration. It demonstrates spontaneous resolution and an increased reaction rate of up to $45 \%$ of the total patients treated of which $2 \%$ with severe reactions. ${ }^{49}$ As shown in Figure 2, there are three different pathways that can induce complement activation: the classical pathway, the alternative pathway, and the lectin pathway. ${ }^{103-105}$ Each pathway involves a cascade of different molecules in the process of recognizing foreign agents, such as NMPs. All pathways eventually lead to the activation of complement protein $\mathrm{C} 3$ through cleavage by $\mathrm{C} 3$ convertase enzymes. ${ }^{96,104}$ Differences in the liposomal structure and experimental conditions can result in major differences in the extent, pathway, and kinetics of complement activation, involving both classical and alternative pathways. ${ }^{49}$

\section{Immunostimulation}

MWCNT are studied for potential use in nanomedicine, showing promising results as drug delivery carriers based on their special physicochemical properties and their transportation abilities along with suitable surface modifications. ${ }^{106-108}$ On the other hand, intraperitoneal administration of MWCNT 


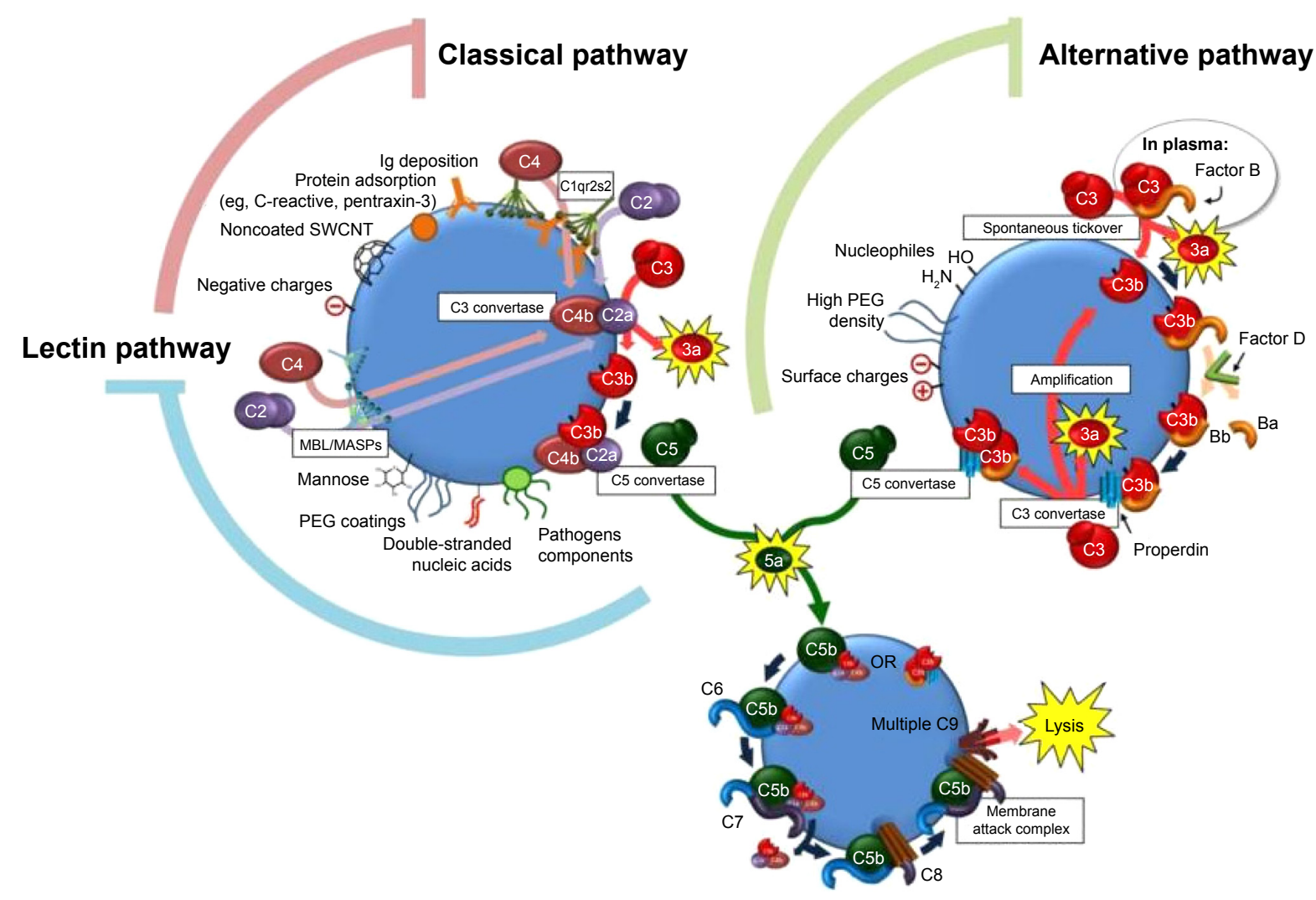

Figure 2 Illustration of the three pathways of complement activation-related pseudoallergy induction.

Notes: Republished with permission of ELSEVIER BV from Interactions of nanomaterials and biological systems: implications to personalized nanomedicine. Zhang XQ, Xu X, Bertrand N, Pridgen E, Swami A, Farokhzad OC. 20I2;64(I3); permission conveyed through Copyright Clearance Center, Inc. ${ }^{105}$

Abbreviations: Ig, immunoglobulin; PEG, polyethylene glycol; SWCNT, single-walled carbon nanotubes; MBL, mannose binding lectin; MASPs, mannose-binding lectinassociated serin protease.

to adult male Wistar rats was reported to result in accumulation of the MWCNT in spleen, reaching a maximum concentration after 48 hours, and resulting in lymphoid hyperplasia and increased numbers of apoptotic cells. ${ }^{109}$ Increasing mitosis in cells of white pulp and changes of oxidative stress and inflammation are also reported after intraperitoneal MWCNT administration. ${ }^{109}$ However, it should be highlighted that MWCNT are a heterogeneous group of materials with quite differing properties, and it has been demonstrated that their potential toxicity depends on the type, surface geometry, diameter, length, and functionalization of these NMs. ${ }^{109}$

Another potential immune effect of NMPs that was reported recently was related to blood coagulation. Cationic dendrimers induced size- and surface charge-dependent leukocyte procoagulant activity (PCA), associated with thrombogenicity in vitro, through a mechanism similar to that seen with doxorubicin. In contrast, anionic and neutral dendrimers did not induce PCA that is associated with thrombogenicity. ${ }^{110}$

Some NMPs may be developed to be administered via the inhalation route. For these NMPs, one needs to be aware of the potential inflammatory responses in the lung, as this has been reported for many different NMs. For example, inhalation exposure of mice to pristine single-walled CNT, which are of interest for biomedical imaging, drug and gene delivery systems, was found to result in acute inflammatory responses in the lung. ${ }^{111}$

\section{Immunosuppression}

NMPs are also potentially capable of causing immunosuppression. Immunosuppression as a side effect can be advantageous if it results in reduced inflammation or autoimmune conditions. However, it can also be an adverse reaction that triggers myelosuppression, thymic suppression, and inhibition of the response of the immune system to infections and malignancies. Myelosuppression is the inhibition of the activity of bone marrow resulting in lower numbers of erythrocytes, lymphocytes, and platelets circulating in the body, which can lead to life-threatening conditions. This is currently one of the most common limiting factors of increasing the doses of cytotoxic cancer medicinal products. ${ }^{77}$ Immunosuppressive effects of NMs are not well studied, perhaps due to the fact that immunosuppression is not an acute toxic 
effect. Therefore, long-term and systematic investigation of the function of the immune system is required to identify this. ${ }^{70,112}$ It has been reported that NMPs are capable of causing myelosuppression. Two doxorubicin-conjugated forms, with polyisobutylcyanoacrylate and polyisohexylcyanoacrylate, showed significantly enhanced myelosuppression induction compared to the free compound. ${ }^{113}$

\section{Regulatory testing of immunotoxicity for NMPs}

Evaluation of the quality, safety, and efficacy of NMPs is based on the existing regulatory frameworks for medicinal products. There is no separate legislation specifically dedicated to nanomedicines. The regulatory guidance documents used to assess and subsequently grant or refuse market authorization of human pharmaceutical products are included in both national and international documents. In Europe, the market authorization of medicines is granted by the European Commission after advice by EMA and national regulatory authorities. The regulatory system for medicinal products is based on the provisions of Directive 2001/83/EC ${ }^{114}$ that details the EU marketing authorization system. The legislation is supported by a series of community guidelines published in "The rules governing medicinal products in the European Union," which include both regulatory and scientific guidelines. All medicinal products, including NMPs, are evaluated on a case-by-case basis. The evaluation includes outcomes of preclinical toxicity studies and human clinical trials. ${ }^{115}$ The scientific guidance documents are aimed to help design the required toxicity testing strategy and perform the toxicity studies needed. A common framework of guidance documents was developed by EMA together with other international regulators, organized in the $\mathrm{ICH} .{ }^{115}$

According to the ICH S8 guideline, all new human pharmaceuticals should be evaluated for potential immunotoxic activity. ${ }^{116}$ The guideline provides a decision tree to design an immunotoxicity testing strategy and describes nonclinical assays that can be used for this purpose. Initial information on immunotoxicity comes from the repeated dose in vivo standard toxicity studies (STS), followed by additional in vivo rodent immunotoxicity studies if needed (Table 2). The STS include assays that are able to detect the following effects: hematological changes, such as leukocytopenia/ leukocytosis, granulocytopenia/granulocytosis, and lymphopenia/lymphocytosis, and alterations in the red blood cell compartment, alterations in immune system organ weights and/or histology (eg, changes in thymus, spleen, lymph nodes, and/or bone marrow), changes in serum globulins not
Table 2 Summary of the standard toxicity tests and the additional immunotoxicity assays recommended by the harmonized ICH S8 guideline

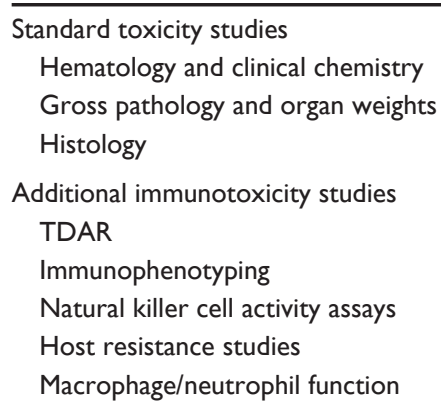

Abbreviations: ICH, International Council for Harmonization of Technical Requirements for Pharmaceuticals for Human Use; TDAR, T-cell-dependent antibody response.

explained by other factors, and changes in serum immunoglobulins, while chronic testing may identify an enhanced infection incidence and an augmented tumor rate without a different possible explanation. ${ }^{116}$ The necessity for extra immunotoxicity studies is judged based on a weight of evidence review put together after the initial evaluation of the outcome of these immunotoxicity parameters in STS. ${ }^{116}$ In addition to the STS outcomes, the weight of evidence review takes into account the class of the compound, the structural similarity to other compounds demonstrating immunosuppressive characteristics, pharmacological properties of the product, the disposition of the drug, and possible clinical findings that could lead to new nonclinical testing. Additional studies that may be recommended include immune function studies in rodents or nonrodent species, such as the T-celldependent antibody response. If such additional tests provide sufficient data to conclude on a risk of immunotoxicity that is considered acceptable and/or can be addressed in a risk management plan, ${ }^{117}$ no extra animal testing might be called for. If the cell types affected in the STS are not known to take part in T-cell-dependent antibody response, then other cell-specific assays need to be selected. ${ }^{116}$ An acceptable study design of the additional rodent studies represents a 28-day study with daily dosing, which includes any of the following immunotoxicity assays: immunophenotyping (flow cytometry or immunohistochemistry), natural killer cell activity assays (performed if immunophenotyping studies demonstrate a change in number or if STS display high viral infectious rates), host resistance studies (testing if the test compound can modulate the host resistance to an infectious agent), macrophage/neutrophil function assays (macrophage/ neutrophil function assessment), and assays to measure cellmediated immunity (in vivo assays where antigens are used for sensitization). ${ }^{116}$ 
EMA has prepared a number of reflection papers (RPs) addressing aspects that need to be taken into consideration for NMPs during the development and assessment procedure. ${ }^{24}$ In particular, RPs have been provided for intravenous liposomal and iron-based nanocolloidal products, block copolymer micelles and the effect of surface coatings. ${ }^{24,118}$ These RPs should be read in connection with a number of $\mathrm{ICH}$ guidelines, including the safety guidelines ICH S4 on chronic toxicity testing, ${ }^{119} \mathrm{~S} 6(\mathrm{R} 1)$ on biological products ${ }^{120}$ and S9 on pharmaceuticals, ${ }^{121}$ and the multidisciplinary guideline M3 (R2) on nonclinical safety studies for the conduct of human clinical trials for pharmaceuticals. ${ }^{122}$ Two of the RPs specifically address aspects of immune toxicity: the RP concerning liposomes ${ }^{123}$ and the RP on the block copolymer micelles. ${ }^{124}$ In more detail, the RP on block copolymer micelles recommends the study of potential complement activation, hematotoxicity, antigenicity, or immunotoxicity, based on the characteristics of the product. ${ }^{124}$ In the RPconcerning liposomes, the investigation of immune reactogenicity assays, in vitro and in vivo, is recommended. These aspects cover testing for CARPA in sensitive animal models and other assays, including complement or macrophage and basophil activation assays. ${ }^{123}$

\section{Discussion}

Development of new, more complex NMPs is advancing. ${ }^{125}$ In order to make optimal use of the expected benefits of these products, it is vital to establish a feasible, scientifically sound safety assessment process specifically tailored to their unique properties. ${ }^{24}$ In light of the obvious interaction of NMPs with the immune system, evaluation of the potential immunotoxicity of NMPs should be given high priority in such an assessment.

\section{Gaps of knowledge in regulatory required immunotoxicity testing of NMPs}

Literature indicates that both NMPs and NMs in general could have adverse effects on the immune system. For NMPs, immune-related effects reported in public literature are limited to CARPA, PCA, and myelosuppression. While advantageous in some cases, modulation of the specific immune system as reported for potential future NMPs based on PEG-GO ${ }^{91}$ may not be desired for other types of NMPs. However, for NMs in general, acute inflammation, oxidative stress, lymphoid hyperplasia, and immunosuppression have also been reported. Due to the nature of the experiments and the types of NMs used in these studies (mostly in vitro studies and rodent studies with metal oxides), the clinical relevance of these effects for NMPs are unknown but cannot be excluded.

The possibility to detect immunotoxic effects of NMPs, like for all medicinal products, increases as they progress from the preclinical to the clinical phase during the drug development process. ${ }^{16}$ The current immunosafety evaluation guideline ICH S8 for conventional pharmaceuticals is only applied in case the type of product or results of the STS indicate that an interaction with the immune system is likely. Due to their uptake by immune-related cells, we recommend that NMPs should always require a thorough safety evaluation of the immune system. The ICH S8 is mainly focused on the detection of direct immunotoxicity, ie, the recommended tests are limited to evaluating the potential for inadvertent immunosuppression and immunostimulation. Such effects can be a result of intended drug-induced immune function modulation. On the other hand, this can occur with nonimmune targeting medicinal products that interact with immune cells or cellular receptors shared by both target tissues and nontarget immune system cells. ${ }^{116}$ Both are possible scenarios for NMPs, but other immunotoxic effects may also be encountered. Examples are hypersensitivity and autoimmunity, which are both not included in ICH S8. Testing for respiratory or systemic allergenicity or drug-specific autoimmunity is not based on standard testing approaches, since no (validated) models are available. ${ }^{116}$ Table 3 shows some examples of immunotoxic effects of NMs or NMPs, and whether or not the testing methods recommended in the ICH S8 guideline are expected to detect the immunotoxic effects reported after exposure to NMs and NMPs. Clear gaps in immunotoxicity screening between state of the art knowledge on immunotoxic effects of NMPs and the recommended testing strategy from the current regulatory guidelines are constituted by the lack of testing on CARPA induction, myelosuppression, inflammasome activation, and hypersensitivity. Validated assays for the investigation of these endpoints are lacking.

The time of exposure to NMPs is an aspect that should be considered in immunotoxicity assessment of these products. The first administration of a nanomedicine can result in CARPA induction to a patient. Repeated administrations may induce hypersensitivity or immunosuppressive reactions. However, depending on the clinical profile of the patients also after a first administration can result to immunosuppressive effects. In general, for most NMPs, administration is repeated. Therefore, most NMPs should be assessed for their full immunotoxic potential. 
Table 3 Examples of immunotoxic effects of NMs or NMPs, and whether the testing methods included in the ICH S8 guideline are expected to detect the immunotoxic effects reported

\begin{tabular}{|c|c|c|c|}
\hline Immunotoxic effects by NMs or NMPs & Testing techniques & ICH S8 guideline & Literature \\
\hline \multicolumn{4}{|l|}{ Immunostimulation } \\
\hline \multirow[t]{2}{*}{ Inflammasome activation (eg, $\mathrm{CeO}_{2}$ and $\mathrm{SiO}_{2} \mathrm{NMs}$ ) } & In vivo studies & - & + \\
\hline & In vitro studies & - & + \\
\hline \multirow[t]{2}{*}{ Inflammation (eg, Au NMs) } & In vivo studies & + & + \\
\hline & In vitro studies & - & + \\
\hline \multicolumn{4}{|l|}{ Hypersensitivity } \\
\hline \multirow[t]{2}{*}{ Lung hypersensitivity $\left(\mathrm{eg}, \mathrm{NiO}\right.$ and $\left.\mathrm{Co}_{3} \mathrm{O}_{4}\right)$} & In vivo studies & - & + \\
\hline & In vitro studies & - & + \\
\hline \multicolumn{4}{|l|}{ CARPA } \\
\hline \multirow[t]{2}{*}{ By liposomes, lipid-based NMs } & In vivo studies & - & + \\
\hline & In vitro studies & - & + \\
\hline \multicolumn{4}{|l|}{ Immunosuppression } \\
\hline \multirow[t]{2}{*}{ Reduction of IgG levels in vivo (eg, AgNMs) } & In vivo studies & + & + \\
\hline & In vitro studies & - & + \\
\hline Myelosuppression (eg, PIBCA-conjugated & In vivo studies & - & + \\
\hline doxorubicin and antimony and cobalt nanoparticles) & In vitro studies & - & + \\
\hline
\end{tabular}

Notes: Lung hypersensitivity refers to inhalatory exposure to NMs and also to NMPs. -, the absence to test on the adverse effects reported in literature; +, testing methods to detect these adverse immune effects.

Abbreviations: CARPA, complement activation-related pseudoallergy; ICH, International Council for Harmonization of Technical Requirements for Pharmaceuticals for Human Use; IgG, immunoglobulin G; NMs, nanomaterials; NMPs, nanomedicinal products; PIBCA, polyisobutylcyanoacrylate.

\section{Recommendations for immunotoxicity testing of NMPs}

To adequately assess the immunosafety of NMPs, safety evaluation guidelines, such as ICH S8, need to be expanded with additional in vitro and in vivo immunotoxicity tests. It should be stressed that expanding the testing strategy does not necessarily mean an increase in the testing requirements for immunotoxicity per se. Instead, such a strategy would be better equipped to evaluate NMPs, waiving certain tests where possible and including other tests where needed. Current guidelines do not specifically require a different testing strategy for organic versus inorganic NMPs. In fact, future NMPs may consist of both organic and inorganic materials, so this distinction may be difficult to make. However, degradation should be considered as an important element in the testing strategy. This may start with in vitro biodegradation studies. Second, testing should result in obtaining kinetic information on the NMPs, revealing its fate and biodegradability and/or dissolution in the body, which would then determine whether further testing is necessary. Furthermore, it is known that NMs may interfere with the read out system of in vitro assays by, eg, light absorbance and/or autofluorescence. ${ }^{126,127}$ Therefore, potential assay interference by the investigational NMPs needs to be carefully evaluated when using in vitro assays for hazard identification in the testing strategy.

A useful source of immunosafety assessment methods of NMPs may be the ISO technical specification for detecting the immunotoxicity of medical devices: ISOTS:10993-20. ${ }^{128}$ This document recommends conducting general immunotoxicity assays first in order to assess the immunosuppression or immunostimulation potential. These assays are categorized as functional and nonfunctional assays. Nonfunctional assays are used to detect morphological and/or quantitative changes, including changes in the lymphoid tissue, the lymphoid cell number, immunoglobulin levels, or other markers of immune function. Functional assays determine activities of cells and/or organs, such as proliferative responses of lymphocytes to mitogens or specific antigens, cytotoxic activity, and specific antibody formation (eg, in response to sheep erythrocytes).

In case immunosuppressive or immunostimulating effects are detected, further testing will follow. The type of testing depends on the immunomodulatory effect. For example, to assess inflammation after exposure to the studied compound, histopathology of the injection or implantation site of the agent is used. Delayed-type hypersensitivity (Type IV) includes testing for antigen-specific cellular inflammatory reactions. However, hypersensitivity cannot be predicted sufficiently by the currently available testing methods, because assays for immediate type hypersensitivity are lacking. In addition, as mentioned earlier for medicinal products, no validated animal models exist to assess autoimmunity. ${ }^{16}$

Other potentially useful sources of reasonably validated immunotoxicity tests may be the guidelines International 
Programme on Chemical Safety Environmental Health Criteria 180 and Organization for Economic Co-operation and Development Test Guideline 407, which provide information on immunotoxicity testing for chemicals and pharmaceuticals, ${ }^{129,130}$ as well as the methods used by the United States Nanotechnology Characterization Laboratory (US-NCL). The US-NCL has developed a number of assays of physicochemical, in vitro and in vivo characterization for engineered $\mathrm{NM}^{131,132}$ including testing methods on immunotoxicity. ${ }^{132}$ A European Nanomedicines Characterization Laboratory is currently being set up, making use of the testing framework from US-NCL as a basis.

\section{Integration of in vitro assays in immunotoxicity assessment}

An aspect that needs consideration in evaluating the risk of adverse immune effects is that the majority of the assays recommended in the current guidance documents are in vivo assays. In vivo assays may be better at predicting the human situation compared to in vitro assays, but they are time consuming, costly, and undesirable from an animal welfare point of view. Research groups and pharma industries involved in developing NMs and NMPs already use a wide range of in vitro and in vivo assays to screen for essential aspects of the immunosafety profile that are not included in the current regulatory guidance. For example, a number of international projects have produced guidelines for testing strategies and test methods for NM safety evaluation, discussing both in vitro and in vivo assays (eg, the FP7 EU projects NANOMMUNE and MARINA), although these guidelines do not specifically address NMPs. ${ }^{133,134}$

However, many obstacles are encountered during the development of predictive in vitro and in vivo assays for the situation in the human body. In general, the pharmacokinetic properties and the behavior of the NMPs inside the cell are not sufficiently known yet. ${ }^{24,135}$ This is exemplified by the finding that plasma concentrations of iron are not directly linked to the therapeutic effect of iron-based nanocolloidal products. This is not surprising in view of the generally fast scavenging of NMs from the circulation by macrophages. Extrapolation of the findings from immunotoxicity assays to human patients is difficult because of the differences between humans and animals in composition, organization, and sensitivity to certain agents of the immune system. Moreover, the sensitivity of the available tests on immunostimulation and immunosuppression is rather low. Nowadays, it is common practice in pharma industries to detect adverse immune effects in vivo and perform further testing in vitro in order to evaluate and identify the mechanism behind the findings. ${ }^{16}$
One immunotoxicity endpoint relevant for NMPs that is currently the focus of a lot of attention is CARPA induction. A wide range of assays is used by different laboratories to evaluate the potential for CARPA induction in vitro and in vivo. These assays include an ELISA of complement $(\mathrm{C})$ cleavage products ( $\mathrm{C} 3 \mathrm{a}, \mathrm{C} 5 \mathrm{a}, \mathrm{C} 4 \mathrm{~d}, \mathrm{Bb}$, and $\mathrm{SC} 5 \mathrm{~b}-9)$, the hemolytic (CH50) C assay, FACS measurement of basophil leukocyte activation, a potentially multiplex bead assay for $\mathrm{C}$ activation by products, the porcine assay of NP-induced cardiopulmonary distress, and other CARPA tests in animals. ${ }^{96}$ Pigs can be used as a useful model to study CARPA as CARPA induction by liposomes in pigs resembles the human situation to a relatively high degree. ${ }^{49}$ Also, a rationale for the use of tests to predict infusion hypersensitivity in the form of a decision tree has been recommended. ${ }^{96}$ Currently, testing for complement activation is required as an additional blood compatibility test for medical devices in the United States. ${ }^{136}$ Introduction of testing on complement activation for NMPs in animal models would help to predict such effects to a better extent and to prevent incidences in the clinic.

Based on extensive experience at the NCL, Dobrovolskaia and $\mathrm{McNeil}^{16}$ recently reported a number of in vitro immunoassays that provide results with a good or fair correlation to in vivo assay outcomes. Good correlation was indicated for the in vitro assays of hemolysis, complement activation, opsonization and phagocytosis, and cytokine secretion assays. Other assays can be regarded as broadly predictive of the functional alterations of the immune system, including CFU-GM, leukocyte proliferation test (immunomodulatory assays), platelet aggregation, leukocyte PCA, and various plasma coagulation tests (thrombogenicity assays). ${ }^{16}$ According to Boraschi et al, ${ }^{18}$ representative in vitro assays should be performed with human primary cells in order to assess human health risk. In vitro assays using cell lines can be used during preclinical testing but only if the biomarkers are reflective of the response seen in vivo.

\section{Conclusion}

The knowledge on NMs and NMPs and their interactions with the immune system is increasing. NMPs are designed to target either the immune system or other tissues, but even in the latter case they will likely reach the immune system eventually. Currently, there are no regulatory documents specifically dedicated to the immunotoxicity assessment of NMPs. Assessment of immunotoxicity is performed based on existing guidelines for conventional medicinal products. Due to the various adverse immunotoxic effects of NMPs reported in clinical practice, it can be questioned whether assessment of this endpoint based on the currently prescribed 
testing methods is sufficient. Effects, such as CARPA, myelosuppression, inflammasome activation, and hypersensitivity, illustrate some of the adverse effects that are not readily detected when current regulatory guidelines are followed. In addition, inflammation and aggravation of allergic responses in experimental animal studies are examples of effects of NMs in general that may also be relevant for NMPs.

There is a clear need for an NMP-specific testing strategy for assessing the function of the immune system, taking into consideration commonly known interferences of NMPs with biological assays. Future actions should point in the direction of developing an improved testing battery based on the proposed strategy, filling the gaps in immunotoxicity testing that were identified. The assays chosen are strongly recommended to have already proven useful to assess a variety of immunotoxic effects for different types of NMs. Finally, such a testing strategy would increase the success of applying these promising products in the clinic, by improving the identification of potential adverse effects.

\section{Take home messages}

- Virtually all NMPs eventually reach the immune system.

- Currently, no regulatory documents are specifically dedicated to the immunotoxicity assessment of NMPs, apart from sections in a number of RPs restricted to specific types of NMP formulations.

- Adverse effects reported after administration of NMPs that are not readily detected when applying current regulatory guidelines for conventional medicinal products include CARPA, inflammasome activation, myelosuppression, and hypersensitivity.

- There is a clear need for an NMPs-specific testing battery to assess the function of the immune system, taking into account potential interferences known to occur for NMs in various toxicity assays.

\section{Acknowledgments}

This work was supported by the project E/132058 "Nanomedicine Benefits \& Risks," funded by the research program "Onderzoeksprogramma Geneesmiddelenketen," a collaboration of Dutch governmental bodies involved in medicine evaluation, authorization, and monitoring. Dr Agnes Oomen and Dr Cornelle Noorlander are acknowledged for their critical review of the article.

\section{Author contributions}

CG drafted the manuscript. MVDZP and REG contributed to the concept and design of the article. MVDZP, REG,
HvL, RJV, and WHdJ were involved in critically revising the article for important intellectual content. All authors read and approved the final article. All authors contributed toward data analysis, drafting and critically revising the paper and agree to be accountable for all aspects of the work.

\section{Disclosure}

The authors report no conflicts of interest in this work.

\section{References}

1. Bamrungsap S, Zhao Z, Chen T, et al. Nanotechnology in therapeutics: a focus on nanoparticles as a drug delivery system. Nanomedicine (Lond). 2012;7(8):1253-1271.

2. European Science Foundation's Forward Look Nanomedicine [homepage on the Internet]. An EMRC Consensus Opinion. 2005. Available from: http://www.esf.org/. Accessed October 20, 2015.

3. Guadagnini R, Halamoda Kenzaoui B, Walker L, et al. Toxicity screenings of nanomaterials: challenges due to interference with assay processes and components of classic in vitro tests. Nanotoxicology. 2015;9(suppl 1):13-24.

4. Wolfram J, Zhu M, Yang Y, et al. Safety of nanoparticles in medicine. Curr Drug Targets. 2014;16(14):1671-1681.

5. Bleeker EAJ, Evertz S, Geertsma R, Peijnenburg WJGM, Westra J, Wijnhoven SWP. Assessing health and environmental risks of nanoparticles: current state of affairs in policy, science and areas of application. RIVM Report 2014-0157;Bilthoven: the Netherlands; 2015.

6. Shi Y, Li X. Biomedical applications and adverse health effects of nanomaterials. J Nanosci Nanotechnol. 2012;12(11):8231-8240.

7. Syed S, Zubair A, Frieri M. Immune response to nanomaterials: implications for medicine and literature review. Curr Allergy Asthma Rep. 2013;13(1):50-57.

8. Jiao Q, Li L, Mu Q, Zhang Q. Immunomodulation of nanoparticles in nanomedicine applications. Biomed Res Int. 2014;2014:426028.

9. Qian S, Wang Q, Zuo Z. Improved brain uptake of peptide-based CNS drugs via alternative routes of administrations of its nanocarrier delivery systems: a promising strategy for CNS targeting delivery of peptides. Expert Opin Drug Metab Toxicol. 2014;10(11):1491-1508.

10. Tinkle S, McNeil SE, Muhlebach S, et al. Nanomedicines: addressing the scientific and regulatory gap. Ann N Y Acad Sci. 2014;1313:35-56.

11. Hafner A, Lovric J, Lakos GP, Pepic I. Nanotherapeutics in the EU: an overview on current state and future directions. Int J Nanomedicine. 2014;9:1005-1023.

12. Li J, Wang Y, Liang R, et al. Recent advances in targeted nanoparticles drug delivery to melanoma. Nanomedicine. 2015;11(3):769-794.

13. Kiessling F, Mertens ME, Grimm J, Lammers T. Nanoparticles for imaging: top or flop? Radiology. 2014;273(1):10-28.

14. Farrera C, Fadeel B. It takes two to tango: Understanding the interactions between engineered nanomaterials and the immune system. Eur J Pharm Biopharm. 2015;95(pt A):3-12.

15. Descotes J. Immunotoxicology: role in the safety assessment of drugs. Drug Saf. 2005;28(2):127-136.

16. Dobrovolskaia MA, McNeil SE. Understanding the correlation between in vitro and in vivo immunotoxicity tests for nanomedicines. $J$ Control Release. 2013;172(2):456-466.

17. Wysowski DK, Swartz L. Adverse drug event surveillance and drug withdrawals in the United States, 1969-2002: the importance of reporting suspected reactions. Arch Intern Med. 2005;165(12): 1363-1369.

18. Boraschi D, Costantino L, Italiani P. Interaction of nanoparticles with immunocompetent cells: nanosafety considerations. Nanomedicine (Lond). 2012;7(1):121-131.

19. ISO. ISO 29701:2010 Nanotechnologies - Endotoxin Test on Nanomaterial Samples for In Vitro Systems - Limulus Amebocyte Lysate (LAL) Test. Geneva: International Organization for Standardization; 2010. 
20. EU. Commission Recommendation of 18 October 2011 on the definition of nanomaterial (Text with EEA relevance) 2011/696/EU. Off J Eur Union. 2011;275:38-40.

21. Panzarini E, Inguscio V, Tenuzzo BA, Carata E, Dini L. Nanomaterials and autophagy: new insights in cancer treatment. Cancers. 2013; 5(1):296-319.

22. National Nanotechnology Initiative [webpage on the Internet]. Frequently Asked Questions. Available from: http://www.nano.gov/ nanotech-101/nanotechnology-facts. Accessed October 20, 2015.

23. European Medicines Agency [webpage on the Internet]. Nanotechnology. Available from: http://www.ema.europa.eu/ema/index. jsp?curl=pages/special_topics/general/general_content_000345. jsp\&mid=WC0b01ac05800baed9. Accessed October 20, 2015.

24. Ehmann F, Sakai-Kato K, Duncan R, et al. Next-generation nanomedicines and nanosimilars: EU regulators' initiatives relating to the development and evaluation of nanomedicines. Nanomedicine (Lond). 2013;8(5):849-856.

25. Health Canada Website [webpage on the Internet]. Policy Statement on Health Canada's Working Definition for Nanomaterial. 2011. Available from: http://www.hc-sc.gc.ca/sr-sr/pubs/nano/pol-eng.php. Accessed October 20, 2015

26. FDA. Considering Whether an FDA-Regulated Product Involves the Application of Nanotechnology. Guidance for Industry: Silver Spring; 2014.

27. Noorlander CW, Kooi MW, Oomen AG, Park MVDZ, Vandebriel RJ, Geertsma RE. Horizon scan of nanomedicinal products. Nanomedicine (Lond). 2015;10(10):1599-1608.

28. Tian X, Yang F, Yang C, et al. Toxicity evaluation of Gd2O3@SiO2 nanoparticles prepared by laser ablation in liquid as MRI contrast agents in vivo. Int J Nanomedicine. 2014;9:4043-4053.

29. Feraheme ${ }^{\circledR}$ (ferumoxytol) injection for intravenous (IV) use [prescribing information]. Waltham: AMAG Pharmaceuticals ${ }^{\circledR}$, Inc; 2013.

30. Bremerich J, Bilecen D, Reimer P. MR angiography with blood pool contrast agents. Eur Radiol. 2007;17(12):3017-3024.

31. Bashir MR, Jaffe TA, Brennan TV, Patel UD, Ellis MJ. Renal transplant imaging using magnetic resonance angiography with a nonnephrotoxic contrast agent. Transplantation. 2013;96(1):91-96.

32. Li X, Kramer MC, van der Loos CM, et al. A pattern of disperse plaque microcalcifications identifies a subset of plaques with high inflammatory burden in patients with acute myocardial infarction. Atherosclerosis. 2011;218(1):83-89.

33. Mumprecht V, Detmar M. Lymphangiogenesis and cancer metastasis. J Cell Mol Med. 2009;13(8A):1405-1416.

34. Bashir MR, Bhatti L, Marin D, Nelson RC. Emerging applications for ferumoxytol as a contrast agent in MRI. J Magn Reson Imaging. 2015; 41(4):884-898.

35. Narang AS, Chang RK, Hussain MA. Pharmaceutical development and regulatory considerations for nanoparticles and nanoparticulate drug delivery systems. J Pharm Sci. 2013;102(11):3867-3882.

36. Weissig V, Pettinger TK, Murdock N. Nanopharmaceuticals (part 1): products on the market. Int J Nanomedicine. 2014;9:4357-4373.

37. Neulasta Website [homepage on the Internet]. Available from: https:// www.neulasta.com/. Accessed October 20, 2015.

38. Fang J, Nakamura H, Maeda H. The EPR effect: unique features of tumor blood vessels for drug delivery, factors involved, and limitations and augmentation of the effect. Adv Drug Deliv Rev. 2011;63(3):136-151.

39. Chen W, Xu N, Xu L, et al. Multifunctional magnetoplasmonic nanoparticle assemblies for cancer therapy and diagnostics (theranostics). Macromol Rapid Commun. 2010;31(2):228-236.

40. Dellinger A, Zhou Z, Connor J, et al. Application of fullerenes in nanomedicine: an update. Nanomedicine (Lond). 2013;8(7):1191-1208.

41. Zhao ZX, Gao SY, Wang JC, et al. Self-assembly nanomicelles based on cationic mPEG-PLA-b-Polyarginine(R15) triblock copolymer for siRNA delivery. Biomaterials. 2012;33(28):6793-6807.

42. Kedar U, Phutane P, Shidhaye S, Kadam V. Advances in polymeric micelles for drug delivery and tumor targeting. Nanomedicine. 2010;6(6): 714-729.
43. Luebke R. Immunotoxicant screening and prioritization in the twentyfirst century. Toxicol Pathol. 2012;40(2):294-299.

44. Naisbitt DJ, Yang EL, Alhaidari M, et al. Towards depersonalized abacavir therapy: chemical modification eliminates HLA-B*57:01-restricted CD8+ T-cell activation. AIDS. 2015;29(18):2385-2395.

45. Pirmohamed M, Breckenridge MA, Kitteringham RN, Park BK. Adverse drug reactions. BMJ. 1998;316(7140):1295-1298.

46. Veraldi A, Costantini AS, Bolejack V, Miligi L, Vineis P, van Loveren H. Immunotoxic effects of chemicals: a matrix for occupational and environmental epidemiological studies. Am J Ind Med. 2006;49(12):1046-1055.

47. Vial T, Descotes J. Immunosuppressive drugs and cancer. Toxicology. 2003;185(3):229-240.

48. Pichler WJ, Beeler A, Keller M, et al. Pharmacological interaction of drugs with immune receptors: the p-i concept. Allergol Int. 2006;55(1):17-25.

49. Szebeni J. Complement activation-related pseudoallergy: a new class of drug-induced acute immune toxicity. Toxicology. 2005;216(2-3): 106-121.

50. De Jong WH, Hagens WI, Krystek P, Burger MC, Sips AJ, Geertsma RE. Particle size-dependent organ distribution of gold nanoparticles after intravenous administration. Biomaterials. 2008;29(12):1912-1919.

51. Lankveld DP, Oomen AG, Krystek P, et al. The kinetics of the tissue distribution of silver nanoparticles of different sizes. Biomaterials. 2010; 31(32):8350-8361.

52. Geraets L, Oomen AG, Krystek P, et al. Tissue distribution and elimination after oral and intravenous administration of different titanium dioxide nanoparticles in rats. Part Fibre Toxicol. 2014;11:30.

53. Dobrovolskaia MA, Aggarwal P, Hall JB, McNeil SE. Preclinical studies to understand nanoparticle interaction with the immune system and its potential effects on nanoparticle biodistribution. Mol Pharm. 2008; 5(4):487-495.

54. Braakhuis HM, Gosens I, Krystek P, et al. Particle size dependent deposition and pulmonary inflammation after short-term inhalation of silver nanoparticles. Part Fibre Toxicol. 2014;11:49.

55. Ivask A, Kurvet I, Kasemets K, et al. Size-dependent toxicity of silver nanoparticles to bacteria, yeast, algae, crustaceans and mammalian cells in vitro. PLoS One. 2014;9(7):e102108.

56. Coradeghini R, Gioria S, Garcia CP, et al. Size-dependent toxicity and cell interaction mechanisms of gold nanoparticles on mouse fibroblasts. Toxicol Lett. 2013;217(3):205-216.

57. Monopoli MP, Aberg C, Salvati A, Dawson KA. Biomolecular coronas provide the biological identity of nanosized materials. Nat Nanotechnol. 2012;7(12):779-786.

58. Lesniak A, Fenaroli F, Monopoli MP, Åberg C, Dawson KA, Salvati A. Effects of the presence or absence of a protein corona on silica nanoparticle uptake and impact on cells. ACS Nano. 2012;6(7):5845-5857.

59. Salvati A, Pitek AS, Monopoli MP, et al. Transferrin-functionalized nanoparticles lose their targeting capabilities when a biomolecule corona adsorbs on the surface. Nat Nanotechnol. 2013;8(2):137-143.

60. Dobrovolskaia MA, Neun BW, Man S, et al. Protein corona composition does not accurately predict hematocompatibility of colloidal gold nanoparticles. Nanomedicine. 2014;10(7):1453-1463.

61. Manke A, Wang L, Rojanasakul Y. Mechanisms of nanoparticle-induced oxidative stress and toxicity. Biomed Res Int. 2013;2013:942916.

62. Kroll A, Dierker C, Rommel C, et al. Cytotoxicity screening of 23 engineered nanomaterials using a test matrix of ten cell lines and three different assays. Part Fibre Toxicol. 2011;8:9.

63. Braakhuis HM, Park MV, Gosens I, De Jong WH, Cassee FR. Physicochemical characteristics of nanomaterials that affect pulmonary inflammation. Part Fibre Toxicol. 2014;11:18

64. Chen PC, Mwakwari SC, Oyelere AK. Gold nanoparticles: from nanomedicine to nanosensing. Nanotechnol Sci Appl. 2008;1:45-66.

65. Deng ZJ, Liang M, Monteiro M, Toth I, Minchin RF. Nanoparticleinduced unfolding of fibrinogen promotes Mac-1 receptor activation and inflammation. Nat Nanotechnol. 2011;6(1):39-44.

66. Sharma M, Salisbury RL, Maurer EI, Hussain SM, Sulentic CE. Gold nanoparticles induce transcriptional activity of NF- $\mathrm{KB}$ in a B-lymphocyte cell line. Nanoscale. 2013;5(9):3747-3756. 
67. Inoue K, Koike E, Yanagisawa R, Hirano S, Nishikawa M, Takano H. Effects of multi-walled carbon nanotubes on a murine allergic airway inflammation model. Toxicol Appl Pharmacol. 2009;237(3):306-316.

68. Inoue K, Yanagisawa R, Koike E, Nishikawa M, Takano H. Repeated pulmonary exposure to single-walled carbon nanotubes exacerbates allergic inflammation of the airway: possible role of oxidative stress. Free Radic Biol Med. 2010;48(7):924-934.

69. Schanen BC, Das S, Reilly CM, et al. Immunomodulation and T helper $\mathrm{TH}(1) / \mathrm{TH}(2)$ response polarization by $\mathrm{CeO}(2)$ and $\mathrm{TiO}(2)$ nanoparticles. PLoS One. 2013;8(5):e62816.

70. Shen CC, Liang HJ, Wang CC, Liao MH, Jan TR. Iron oxide nanoparticles suppressed $\mathrm{T}$ helper 1 cell-mediated immunity in a murine model of delayed-type hypersensitivity. Int J Nanomedicine. 2012;7: 2729-2737.

71. Moller P, Christophersen DV, Jensen DM, et al. Role of oxidative stress in carbon nanotube-generated health effects. Arch Toxicol. 2014; 88(11):1939-1964.

72. De Jong WH, Van Der Ven LT, Sleijffers A, et al. Systemic and immunotoxicity of silver nanoparticles in an intravenous 28 days repeated dose toxicity study in rats. Biomaterials. 2013;34(33):8333-8343.

73. Vandebriel RJ, Tonk ECM, de la Fonteyne-Blankestijn LJ, et al. Immunotoxicity of silver nanoparticles in an intravenous 28-day repeated-dose toxicity study in rats. Particle and Fibre Toxicology. 2014; $11: 21$.

74. van der Zande M, Vandebriel RJ, Van Doren E, et al. Distribution, elimination, and toxicity of silver nanoparticles and silver ions in rats after 28-day oral exposure. ACS Nano. 2012;6(8):7427-7442.

75. Tamayo I, Irache JM, Mansilla C, Ochoa-Reparaz J, Lasarte JJ, Gamazo C. Poly(anhydride) nanoparticles act as active Th1 adjuvants through toll-like receptor exploitation. Clin Vaccine Immunol. 2010; 17(9):1356-1362.

76. Lucarelli M, Gatti AM, Savarino G, et al. Innate defence functions of macrophages can be biased by nano-sized ceramic and metallic particles. Eur Cytokine Netw. 2004;15(4):339-346.

77. Ilinskaya AN, Dobrovolskaia MA. Immunosuppressive and antiinflammatory properties of engineered nanomaterials. Br J Pharmacol. 2014;171(17):3988-4000.

78. Mohamed BM, Verma NK, Davies AM, et al. Citrullination of proteins: a common post-translational modification pathway induced by different nanoparticles in vitro and in vivo. Nanomedicine (Lond). 2012;7(8): 1181-1195.

79. Verma NK, Conroy J, Lyons PE, et al. Autophagy induction by silver nanowires: a new aspect in the biocompatibility assessment of nanocomposite thin films. Toxicol Appl Pharmacol. 2012;264(3):451-461.

80. Harris J, Hartman M, Roche C, et al. Autophagy controls IL-1beta secretion by targeting pro-IL-1 beta for degradation. J Biol Chem. 2011;286(11): 9587-9597.

81. Duan J, Yu Y, Yu Y, et al. Silica nanoparticles enhance autophagic activity, disturb endothelial cell homeostasis and impair angiogenesis. Part Fibre Toxicol. 2014;11:50.

82. Li JJ, Hartono D, Ong CN, Bay BH, Yung LY. Autophagy and oxidative stress associated with gold nanoparticles. Biomaterials. 2010; 31(23):5996-6003.

83. Liu HL, Zhang YL, Yang N, et al. A functionalized single-walled carbon nanotubeinduced autophagic cell death in human lung cells through Akt-TSC2-mTOR signaling. Cell Death Dis. 2011;2:e159.

84. Seleverstov O, Zabirnyk O, Zscharnack M, et al. Quantum dots for human mesenchymal stem cells labeling, a size-dependent autophagy activation. Nano Lett. 2006;6(12):2829-2832.

85. Bastus NG, Sanchez-Tillo E, Pujals S, et al. Homogeneous conjugation of peptides onto gold nanoparticles enhances macrophage response. ACS Nano. 2009;3(6):1335-1344.

86. Niidome T, Yamagata M, Okamoto Y, et al. PEG-modified gold nanorods with a stealth character for in vivo applications. J Control Release. 2006;114(3):343-347.

87. Lankveld DP, Rayavarapu RG, Krystek P, et al. Blood clearance and tissue distribution of PEGylated and non-PEGylated gold nanorods after intravenous administration in rats. Nanomedicine (Lond). 2011;6(2):339-349.
88. Liu JH, Yang ST, Wang H, Chang Y, Cao A, Liu Y. Effect of size and dose on the biodistribution of graphene oxide in mice. Nanomedicine (Lond). 2012;7(12):1801-1812.

89. Yang K, Gong H, Shi X, Wan J, Zhang Y, Liu Z. In vivo biodistribution and toxicology of functionalized nano-graphene oxide in mice after oral and intraperitoneal administration. Biomaterials. 2013;34(11): 2787-2795.

90. Yang K, Wan J, Zhang S, Zhang Y, Lee ST, Liu Z. In vivo pharmacokinetics, long-term biodistribution, and toxicology of PEGylated graphene in mice. ACS Nano. 2011;5(1):516-522.

91. Wu HY, Lin KJ, Wang PY, et al. Polyethylene glycol-coated graphene oxide attenuates antigen-specific IgE production and enhanced antigeninduced T-cell reactivity in ovalbumin-sensitized BALB/c mice. Int J Nanomedicine. 2014;9:4257-4266.

92. Mahapatro A, Singh DK. Biodegradable nanoparticles are excellent vehicle for site directed in-vivo delivery of drugs and vaccines. J Nanobiotechnology. 2011;9:55.

93. Danhier F, Ansorena E, Silva JM, Coco R, Le Breton A, Preat V. PLGA-based nanoparticles: an overview of biomedical applications. J Control Release. 2012;161(2):505-522.

94. Kumari A, Yadav SK, Yadav SC. Biodegradable polymeric nanoparticles based drug delivery systems. Colloids Surf B Biointerfaces. 2010;75(1):1-18

95. Wacker M. Nanocarriers for intravenous injection - the long hard road to the market. Int J Pharm. 2013;457(1):50-62.

96. Szebeni J. Hemocompatibility testing for nanomedicines and biologicals: predictive assays for complement mediated infusion reactions. European Journal of Nanomedicine. 2012;4(1):33-53.

97. Hong SJ, Wong JT, Bloch KJ. Reactions to radiocontrast media Allergy Asthma Proc. 2002;23(5):347-351.

98. Kris MG, O’Connell JP, Gralla RJ, et al. Phase I trial of taxol given as a 3-hour infusion every 21 days. Cancer Treat Rep. 1986;70(5):605-607.

99. Vercellotti GM, Hammerschmidt DE, Craddock PR, Jacob HS Activation of plasma complement by perfluorocarbon artificial blood: probable mechanism of adverse pulmonary reactions in treated patients and rationale for corticosteroids prophylaxis. Blood. 1982;59(6):1299-1304.

100. Chanan-Khan A, Szebeni J, Savay S, et al. Complement activation following first exposure to pegylated liposomal doxorubicin (Doxil): possible role in hypersensitivity reactions. Ann Oncol. 2003;14(9): 1430-1437.

101. Ambisome [homepage on the Internet]. Package Label. Available from: http://www.ambisome.com. Accessed October 20, 2015.

102. Lazarou J, Pomeranz BH, Corey PN. Incidence of adverse drug reactions in hospitalized patients: a meta-analysis of prospective studies. JAMA. 1998;279(15):1200-1205.

103. Moghimi SM. Cancer nanomedicine and the complement system activation paradigm: anaphylaxis and tumour growth. J Control Release. 2014;190:556-562.

104. Moghimi SM, Andersen AJ, Ahmadvand D, Wibroe PP, Andresen TL, Hunter AC. Material properties in complement activation. Adv Drug Deliv Rev. 2011;63(12):1000-1007.

105. Zhang XQ, Xu X, Bertrand N, Pridgen E, Swami A, Farokhzad OC. Interactions of nanomaterials and biological systems: implications to personalized nanomedicine. Adv Drug Deliv Rev. 2012;64(13):1363-1384.

106. Zhang W, Zhang Z, Zhang Y. The application of carbon nanotubes in target drug delivery systems for cancer therapies. Nanoscale Res Lett. 2011;6:555.

107. Kuznik N, Tomczyk MM, Wyskocka M, et al. Amalgamation of complex iron(III) ions and iron nanoclusters with MWCNTs as a route to potential T2 MRI contrast agents. Int J Nanomedicine. 2015;10:3581-3591.

108. Cao X, Tao L, Wen S, Hou W, Shi X. Hyaluronic acid-modified multiwalled carbon nanotubes for targeted delivery of doxorubicin into cancer cells. Carbohydr Res. 2015;405:70-77.

109. Clichici S, Biris AR, Catoi C, Filip A, Tabaran F. Short-term splenic impact of single-strand DNA functionalized multi-walled carbon nanotubes intraperitoneally injected in rats. $J$ Appl Toxicol. 2014;34(4):332-344. 
110. Dobrovolskaia MA, Patri AK, Potter TM, Rodriguez JC, Hall JB, McNeil SE. Dendrimer-induced leukocyte procoagulant activity depends on particle size and surface charge. Nanomedicine (Lond). 2012;7(2):245-255.

111. Park EJ, Zahari NE, Kang MS, et al. Toxic response of HIPCO singlewalled carbon nanotubes in mice and RAW264.7 macrophage cells. Toxicol Lett. 2014;229(1):167-177.

112. Mitchell LA, Lauer FT, Burchiel SW, McDonald JD. Mechanisms for how inhaled multiwalled carbon nanotubes suppress systemic immune function in mice. Nat Nanotechnol. 2009;4(7):451-456.

113. Gibaud S, Andreux JP, Weingarten C, Renard M, Couvreur P. Increased bone marrow toxicity of doxorubicin bound to nanoparticles. Eur J Cancer. 1994;30A(6):820-826.

114. EC. Directive 2001/83/EC of the European Parliament and of the Council of 6 November 2001 on the Community code relating to medicinal products for human use. OJL. 2001;311:67-128.

115. Kawabata TT, Evans EW. Development of immunotoxicity testing strategies for immunomodulatory drugs. Toxicol Pathol. 2012;40(2): 288-293.

116. EMA. European Medicines Agency - Committee for Medicinal Products for Human Use (CHMP). ICH Topic S8 Immunotoxicity Studies for Human Pharmaceuticals. London: EMA; 2006. CHMP/167235/2004.

117. EMA. European Medicines Agency-Committee for Medicinal Products for Human Use (CHMP). ICH Topic E 2 E Pharmacovigilance Planning (Pvp). London: EMA; 2005. CPMP/ICH/5716/03.

118. EMA [webpage on the Internet]. Reflection Paper List. Available from: http://www.ema.europa.eu/ema/index.jsp?curl=pages/regulation/ general/general_content_000564.jsp\&mid=WC0b01ac05806403e0. Accessed October 20, 2015.

119. EMA. European Medicines Agency-Committee for Medicinal Products for Human Use (CHMP). ICH Topic S 4 Duration of Chronic Toxicity Testing in Animals (Rodent and Non Rodent Toxicity Testing). London: EMA; 1999. CPMP/ICH/300/95.

120. EMA. European Medicines Agency-Committee for Medicinal Products for Human Use (CHMP). ICH Guideline S6 (R1) - Preclinical Safety Evaluation of Biotechnology-Derived Pharmaceuticals. London: EMA; 2011. EMA/CHMP/ICH/731268/1998.

121. EMA. European Medicines Agency - Committee for Medicinal Products for Human Use (CHMP). ICH Guideline S9 on Nonclinical Evaluation for Anticancer Pharmaceuticals. London: EMA; 2010. EMA/CHMP/ICH/646107/2008.

122. EMA. European Medicines Agency - Committee for Medicinal Products for Human Use (CHMP). ICH Guideline M3(R2) on NonClinical Safety Studies for the Conduct of Human Clinical Trials and Marketing Authorisation for Pharmaceuticals. London: EMA; 2009. EMA/CPMP/ICH/286/1995.

123. EMA. European Medicines Agency - Committee for Medicinal Products for Human Use (CHMP). Reflection Paper on the Data Requirements for Intravenous Liposomal Products Developed with Reference to an Innovator Liposomal Product. London: EMA; 2013. EMA/CHMP/806058/2009/Rev. 02.

124. EMA. European Medicines Agency-Committee for Medicinal Products for Human Use (CHMP). Joint MHLW/EMA Reflection Paper on the Development of 4 Block Copolymer Micelle Medicinal Products. London: EMA; 2013. EMA/CHMP/13099/2013.

International Journal of Nanomedicine

\section{Publish your work in this journal}

The International Journal of Nanomedicine is an international, peerreviewed journal focusing on the application of nanotechnology in diagnostics, therapeutics, and drug delivery systems throughout the biomedical field. This journal is indexed on PubMed Central, MedLine, CAS, SciSearch $®$, Current Contents ${ }^{\circledR} /$ Clinical Medicine,
125. Duncan R, Gaspar R. Nanomedicine(s) under the microscope. Mol Pharm. 2011;8(6):2101-2141.

126. Park MV, Lankveld DP, van Loveren H, de Jong WH. The status of in vitro toxicity studies in the risk assessment of nanomaterials. Nanomedicine (Lond). 2009;4(6):669-685.

127. Kroll A, Pillukat MH, Hahn D, Schnekenburger J. Current in vitro methods in nanoparticle risk assessment: limitations and challenges. Eur J Pharm Biopharm. 2009;72(2):370-377.

128. ISO. ISO/TS 10993-20: Biological evaluation of medical devices. Part 20: Principles and methods for immunotoxicology testing of medical devices. ISO, International Organization for Standardization, Geneva, Switzerland 2006.

129. OECD. OECD 407, Repeated Dose 28-Day Oral Toxicity Study in Rodents.

130. IPCS. International Programme on Chemical Safety (IPCS)-ENVIRONMENTAL HEALTH CRITERIA 180: Principles and Methods for Assessing Direct Immunotoxicity Associated with Exposure to Chemicals. Geneva: World Health Organization; 1996.

131. Garduno-Balderas LG, Urrutia-Ortega IM, Medina-Reyes EI, Chirino YI. Difficulties in establishing regulations for engineered nanomaterials and considerations for policy makers: avoiding an unbalance between benefits and risks. J Appl Toxicol. 2015;35(10): 1073-1085.

132. Nanotechnology Characterization Laboratory (NCL) [hompage on the Internet]. Available from: http://ncl.cancer.gov/. Accessed October 20,2015 .

133. MARINA [home page on the Internet]. Managing Risks of Nanomaterials. 2015. Available from: http://www.marina-fp7.eu/. Accessed October 20, 2015.

134. NANOMMUNE. Comprehensive Assessment of Hazardous Effects of Engineered Nanomaterials on the Immune System. 2015. Available from: http://www.nanosafetycluster.eu/eu-nanosafety-cluster-projects/ seventh-framework-programme-projects/nanommune.html. Accessed April 12, 2016.

135. EMA. European Medicines Agency-Committee for Medicinal Products for Human Use (CHMP). DRAFT Reflection Paper on the Data Requirements for Intravenous Iron-Based Nano-Colloidal Products Developed with Reference to an Innovator Medicinal Product. London: EMA; 2013. EMA/CHMP/SWP/620008/2012.

136. FDA. Draft guidance for Industry and Food and Drug Administration Staff. DRAFT guidance: Use of International Standard ISO 10993, "Biological Evaluation of Medical Devices Part 1: Evaluation and Testing”. This guidance document is being distributed for comment purposes only. Document issued on April 23, 2013; 2013.

137. Chen Q, Xue Y, Sun J. Kupffer cell-mediated hepatic injury induced by silica nanoparticles in vitro and in vivo. Int J Nanomedicine. 2013;8: 1129-1140.

138. Park EJ, Yi J, Chung KH, Ryu DY, Choi J, Park K. Oxidative stress and apoptosis induced by titanium dioxide nanoparticles in cultured BEAS-2B cells. Toxicol Lett. 2008;180(3):222-229.

Journal Citation Reports/Science Edition, EMBase, Scopus and the Elsevier Bibliographic databases. The manuscript management system is completely online and includes a very quick and fair peer-review system, which is all easy to use. Visit http://www.dovepress.com/ testimonials.php to read real quotes from published authors. 